\title{
Toxicology Finding
}

National Cancer Institute

\section{Source}

National Cancer Institute. Toxicology Finding. NCI Thesaurus. Code C70920.

The results of any analysis that determine the toxicity of a chemical compound. 